\title{
Estimation of economic losses due to Peste de Petits Ruminants in small ruminants in India
}

\author{
B. Singh ${ }^{1}$, D. Bardhan ${ }^{1}$, M. R. Verma ${ }^{1}$, Shiv Prasad ${ }^{1}$ and D.K. Sinha ${ }^{2}$ \\ 1. Division of Livestock Economics, Statistics and Information Technology, Indian Veterinary Research \\ Institute, Izatnagar - 243 122, Bareilly, Uttar Pradesh, India; 2. Centre for Animal Disease Research and Diagnosis \\ (CADRAD), Indian Veterinary Research Institute, Izatnagar - 243 122, Bareilly, Uttar Pradesh, India \\ Corresponding author: D. Bardhan, email: dwaipayanbardhan@gmail.com, B. Singh: bsingh@ivri.res.in, M.R. Verma: \\ medramverma@rediffmail.com, Shiv Prasad: shivprasad@ivri.res.in, D.K. Sinha: sinhaivri@rediffmail.com \\ Received: 24-01-2014, Revised: 27-02-2014, Accepted: 05-03-2014, Published online: 01-04-2014
}

doi: 10.14202/vetworld.2014.194-199

How to cite this article: Singh B, Bardhan D, Verma MR, Prasad S and Sinha DK (2014) Estimation of economic losses due to Peste de Petits Ruminants in small ruminants in India, Veterinary World 7(4): 194-199.

\begin{abstract}
Aim: To develop a simple mathematical model to assess the losses due to peste des petits ruminants (PPR) in small ruminants in India.

Materials and Methods: The study was based on cases and deaths in goats and sheep due to PPR from the average combined data on ovine/caprine as published by Government of India for the last 5 years (2008-2012). All possible direct and indirect losses due to the disease, viz. mortality losses, losses due to direct reduction in milk/wool yield, losses due to reproduction failure, body weight losses, treatment costs and opportunity costs, were considered to provide estimate of annual economic losses due to PPR in sheep and goats in India. Based on cases and deaths as reported in sample survey studies, the annual economic loss was also estimated.
\end{abstract}

Results: On the basis of data reported by Government of India, the study has shown average annual economic loss of Rs. 167.83 lacs, of which Rs. 125.67 lacs and Rs. 42.16 lacs respectively are due to the incidence of the disease in goats and sheep. Morbidity losses constituted the greater share of the total loss in both goats and sheep (56.99\% and 61.34\%, respectively). Among different components of morbidity loss, direct body weight loss was the most significant in both goats and sheep. Based on cases and deaths as reported in sample survey studies, the estimated annual economic loss due to PPR in goats and sheep is Rs. 8895.12 crores, of which Rs. 5477.48 and Rs. 3417.64 crores respectively are due to the disease in goats and sheep.

Conclusion: The low economic losses as reported based on Government of India data points towards underreporting of cases and deaths due to the disease. The study thus revealed a significant loss due to PPR in small ruminants on a large scale.

Keywords: goat, incidence, economic loss, economic modeling of diseases, PPR.

\section{Introduction}

Sheep and goats are one of the major livestock species reared by many of the world's poor. Goats, 'the cattle of the poor', and sheep are reared as sources not only for milk, wool and meat for family consumption but also as a source of income that could be easily mobilized for paying some of the household expenditures specially in lean times. In addition to this important economic role, sheep and goats have significant role in socio-cultural activities such as funerals, dowries, festivals and holidays, etc. However, sheep and goat populations are threatened by number of diseases which have been considered as major constraint in small ruminant development in recent years.

Peste des petits ruminants (PPR) is an acute contagious disease affecting goats and sheep population in the Indian subcontinent [1]. PPR is characterized by high fever, anorexia, necrosis and ulceration of mucous membrane, inflammation of gastrointestinal tract leading to diarrhea, ocular and nasal puruluent discharge, pneumonia and high mortality $[2,3]$. The

Copyright: The authors. This article is an open access article licensed under the terms of the Creative Commons Attribution License (http://creativecommons.org/licenses/by/2.0) which permits unrestricted use, distribution and reproduction in any medium, provided the work is properly cited. disease may affect up to $100 \%$ of animals in the flock in an outbreak with deaths between $20 \%$ to $90 \%$ [4]. The disease is proving to be costly and is considered one of the most important health constraints in rearing of small ruminants [5]. In a study based on official Government of India reports covering a period of 15 years (1991-2005), it was reported that PPR accounted for maximum incidence $(32.3 \%)$ and deaths $(41.5 \%)$ due to all diseases in goats in India [6]. Apart from loss on account of mortality, PPR causes severe morbidity loss in terms of production loss, abortion, cost of controlling the disease and restriction in local trade and export [7]. The World Organization for Animal Health has identified PPR as a notifiable and economically important transboundary viral disease of sheep and goats associated with high morbidity and mortality [5]. Presently, PPR outbreaks are reported regularly and the disease is considered to be endemic throughout India [8].

In spite of the economic significance of a disease like PPR, scant literature is available in Indian context documenting the financial losses due to the disease. Estimation of economic losses is important not only as a description of the actual situation but also for how much and to what extent the losses can be avoided and 
Table-1. Components of losses due to PPR in sheep and goats

A. Mortality loss

B. Wool loss

C. Reproductive failure

a. Increased inter lambing/kidding period

b. Increased abortions

D. Body weight loss

E. Treatment cost

F. Opportunity Costs
Table-2. Treatment cost of PPR affected sheep/goat

\begin{tabular}{lccc}
\hline Medicines for treatment & Dose & $\begin{array}{c}\text { Duration of } \\
\text { course }\end{array}$ & Total cost \\
\hline Antibiotics (Amoxycillin plus sulbactum) & $10 \mathrm{mg} / \mathrm{kg} \mathrm{bwt}$ & 5 days & Rs. 150.00 \\
NSAID (Meloxicam) & $1 \mathrm{ml} / 10 \mathrm{~kg} \mathrm{bwt}$ & 3 days & Rs 20.00 \\
Antihistaminic (Phenriamin meleate) & $2 \mathrm{ml} \mathrm{l/M} \mathrm{OD}$ & 2 days & Rs 10.00 \\
Vitamin B complex & $3-5 \mathrm{ml} \mathrm{OD} \mathrm{l/M}$ & 5 days & Rs 50.00 \\
Expectorant (Pd. Caflon) & $6-12 \mathrm{gm}$ ODPO & 5 days & Rs. 20.00 \\
Fluid therapy (Dextrose with normal saline) & $100 \mathrm{ml} \mathrm{OD} \mathrm{I/V}$ & 3 days & Rs. 45.00 \\
Expenditure for medicine & & & Rs 295.00 \\
Visit charge of paravet @ 10.00/day/goat for 5 days & & Rs. 50.00 \\
Total expenditure & & Rs. 345.00 \\
\hline
\end{tabular}

risk of disease can be reduced. Some studies have been carried out that document the economic losses due to PPR in certain regions of India [9]. However, the assessment of losses caused due to occurrence of the disease in small ruminants at national level has not been carried out. Singh and Prasad [6] had reported average annual loss of Rs. 91.42 lacs due to PPR in goats on the basis of average data reported by Government of India during the period 1991-2005. This loss may be very small due to under reporting of number of cases and deaths.

The present study was designed to provide an estimate of annual economic losses due to PPR in sheep and goats in India on the basis of a mathematical model by considering all possible direct and indirect losses.

\section{Materials and Methods}

The computation of the economic loss due to PPR is based on two sets of data, viz. (i) data reported by Department of Dairying Animal Husbandry and Fisheries, Government of India and (ii) data based on sample survey studies. Data used for computing economic losses are taken from secondary sources, viz. Basic Animal Husbandry Statistics, Livestock Census Reports and published information in scientific journals. The data on the number of incidence and deaths due to PPR were obtained from the average combined data on ovine/caprine in Annual Reports of Department of Animal Husbandry and Dairying, Ministry of Agriculture, Government of India for the last 5 years (2008-2012). The number of cases and deaths in each species, viz. sheep and goat were then obtained on the basis of proportional incidence and deaths in sheep and goat $[10,11]$. The data on mortality and morbidity were compiled from sample surveys carried out in the states of Chattisgarh and Madhya Pradesh [10,11].

Evaluation of losses due to PPR: The total economic losses due to PPR were worked out as sum of morbidity and mortality losses and treatment cost. The components of losses due to PPR in sheep and goats are summarized in Table-1. The methodology for sheep and goat is given as under:

Goats: The total economic loss $\left(\mathrm{T}_{\mathrm{L}}\right)$ due to PPR in goats is worked out as sum of (A) mortality loss, (B) direct loss in milk yield, (C) Losses due to reproductive failure, (D) Loss in body weight, (E) cost of treatment of affected goats and (F) opportunity costs.

The total economic loss is expressed as

$\mathrm{T}_{\mathrm{L}}=\mathrm{A}+\mathrm{B}+\mathrm{C}+\mathrm{D}+\mathrm{E}+\mathrm{F}$

A. Loss from mortality: This was worked out as the product of number of died animals $\left(\mathrm{D}_{\mathrm{AG}}\right.$, more than 12 months; $\mathrm{D}_{\mathrm{YG}}$, between 6 to 12 months and $\mathrm{D}_{\mathrm{KG}}$, below 6 months) due to PPR and probable market value $\left(\mathrm{P}_{\mathrm{AG}}\right.$, $\mathrm{P}_{\mathrm{YG}}$ and $\mathrm{P}_{\mathrm{KG}}$, respectively) of the animal. Mortality losses were divided as per losses in different age groups because significant differences in age-wise deaths have been reported in earlier studies $[8,12,13,14]$. $\mathrm{A}=\mathrm{D}_{\mathrm{AG}} \mathrm{P}_{\mathrm{AG}}+\mathrm{D}_{\mathrm{YG}} \mathrm{P}_{\mathrm{YG}}+\mathrm{D}_{\mathrm{KG}} \mathrm{P}_{\mathrm{KG}}$

B. Value of direct loss through reduction in milk yield: For the proportion of goats in milk in a year, the losses were expressed in terms of reduction in milk yield, which through the price of milk could be directly converted into monetary terms. The loss due to direct decline in milk production was calculated using the formula:

$\mathrm{B}=(\mathrm{I}-\mathrm{D}) \mathrm{P}_{\mathrm{L}} \mathrm{LZM}$

\section{Losses due to reproductive failure:}

$$
\mathrm{C}=\mathrm{C}_{1}+\mathrm{C}_{2}
$$

$\mathrm{C}_{1}$. Losses due to increased abortions

$$
\mathrm{C}_{1}=\mathrm{C}_{11}+\mathrm{C}_{12}
$$

$\mathrm{C}_{11}$. Milk loss due to increased abortions

The disease can cause abortions, particularly in the late pregnancies and leads to increased inter kidding period, besides loss of kids. Assuming the time for abortion as 3.5 months from conception, and a delay of six months in the next conception, the inter kidding period gets increased by 9.5 months in aborting cases, and the milk loss due to increased abortions was estimated from following equation:

$$
\mathrm{C}_{11}=\left[\left(12 / \mathrm{K}_{\mathrm{I}}\right)-\left\{12 /\left(\mathrm{K}_{\mathrm{I}}+9.5\right)\right\}\right](\mathrm{I}-\mathrm{D}) \mathrm{P}_{\mathrm{L}} \mathrm{AZM}
$$

$\mathrm{C}_{12}$. Cost of live weight loss due to increased abortions Reduction in the number of kids due to more abortions in goats after infection with a disease caused loss in live body weight, which was estimated by the formulae:

$$
\mathrm{C}_{12}=\left[\left(12 / \mathrm{K}_{\mathrm{I}}\right)-\left\{12 /\left(\mathrm{K}_{\mathrm{I}}+9.5\right)\right\}\right](\mathrm{I}-\mathrm{D}) \mathrm{P}_{\mathrm{L}} \mathrm{AN}_{\mathrm{K}} \mathrm{P}_{\mathrm{C}}
$$

$\mathrm{C}_{2}$. Losses due to increased inter kidding interval

$$
\mathrm{C}_{2}=\mathrm{C}_{21}+\mathrm{C}_{22}
$$

$\mathrm{C}_{21}$. Milk loss due to increased inter kidding interval

The problem of non-conception caused by a disease increases the inter kidding period and thus lower number of goats will be in milk at any given time. As a result of non-conception or delayed conception, 
the milk output gets reduced. The loss of milk was calculated by the reduction in lactating goats in any year multiplied by the average milk yield per in-milk goat per year and by the price $\mathrm{M}$.

$$
\mathrm{C}_{21}=\left[\left(12 / \mathrm{K}_{\mathrm{I}}\right)-\left\{12 /\left(\mathrm{K}_{\mathrm{I}}+\mathrm{W}\right)\right\}\right](\mathrm{I}-\mathrm{D}) \mathrm{P}_{\mathrm{L}}(1-\mathrm{A}) \mathrm{ZM}
$$

$\mathrm{C}_{22}$. Cost of live weight loss due to increased inter kidding interval

Reduction in number of kids due to increased inter kidding period after infection with a disease caused loss in the live body weight. Such losses were obtained by the formula:

$$
\begin{aligned}
& \mathrm{C}_{22}=\left[\left(12 / \mathrm{K}_{\mathrm{I}}\right)-\left\{12 /\left(\mathrm{K}_{\mathrm{I}}+\mathrm{W}\right)\right\}\right](\mathrm{I}-\mathrm{D}) \mathrm{P}_{\mathrm{L}}(1-\mathrm{A}) \\
& \mathrm{N}_{\mathrm{K}} \mathrm{P}_{\mathrm{C}}
\end{aligned}
$$

D. Loss in body weight: The value of direct loss due to reduction in body weight is estimated by the formulae:

\section{E. Cost of treatment}

$$
\mathrm{D}=(\mathrm{I}-\mathrm{D})\left(1-\mathrm{P}_{\mathrm{L}}\right) \mathrm{W}_{\mathrm{L}} \mathrm{W}_{\mathrm{A}} \mathrm{P}_{\mathrm{W}}
$$

$$
\mathrm{E}=\mathrm{IT}_{\mathrm{C}}
$$

F. Opportunity costs: These costs are difficult to quantify where records and estimates on cost of feeding, rearing and transportation, and extra human labour for sick animals and disinfection of the shed are lacking. In absence of any suitable data in this regard, these costs are assumed approximately $5 \%$ of the cost of animals, i.e.

$$
\mathrm{F}=\left(\mathrm{S}_{\mathrm{AG}} \mathrm{P}_{\mathrm{AG}}+\mathrm{S}_{\mathrm{YG}} \mathrm{P}_{\mathrm{YG}}+\mathrm{S}_{\mathrm{KG}} \mathrm{P}_{\mathrm{KG}}\right) \times 0.05
$$

Where, $\mathrm{S}_{\mathrm{AG}}, \mathrm{S}_{\mathrm{YG}}$ and $\mathrm{S}_{\mathrm{KG}}$ and $\mathrm{P}_{\mathrm{AG}}, \mathrm{P}_{\mathrm{YG}}$ and $\mathrm{P}_{\mathrm{KG}}$ are the number of survived animals and average market values of the animals of age below 6 months, 6-12 months and more than 12 months, separately.

Sheep: The total economic loss due to PPR in sheep is worked out as sum of (A) mortality loss), (B) direct loss in wool yield, (C) Losses due to reproductive failure, (D) Loss in body weight, (E) cost of treatment of affected sheep and (F) opportunity costs.

$$
\mathrm{T}_{\mathrm{L}}=\mathrm{A}+\mathrm{B}+\mathrm{C}+\mathrm{D}+\mathrm{E}+\mathrm{F}
$$

A. Loss from mortality: This was worked out as the product of number of died animals $\left(\mathrm{D}_{\mathrm{AS}}\right.$, more than 12 months; $\mathrm{D}_{\mathrm{YS}}$, between 6 to 12 months and $\mathrm{D}_{\mathrm{KS}}$, below 6 months) due to PPR and probable average market value $\left(\mathrm{P}_{\mathrm{AS}}, \mathrm{P}_{\mathrm{YS}}\right.$ and $\mathrm{P}_{\mathrm{KS}}$, respectively) of the animal.

$$
\mathrm{A}=\mathrm{D}_{\mathrm{AS}} \mathrm{P}_{\mathrm{AS}}+\mathrm{D}_{\mathrm{YS}} \mathrm{P}_{\mathrm{YS}}+\mathrm{D}_{\mathrm{KS}} \mathrm{P}_{\mathrm{KS}}
$$

B. Direct loss in wool yield: For the proportion of sheep in shearing age in a year, the loss is expressed in terms of the reduced wool yield. The price of wool can be directly converted into monetary terms. The fall in wool production in diseased sheep is never gained later and therefore constitutes a significant form of loss. The loss due to the direct decline wool yield is estimated from the formulae:

$$
\mathrm{B}=(\mathrm{I}-\mathrm{D}) \mathrm{P}_{\mathrm{H}} \mathrm{Y}_{\mathrm{L}} \mathrm{Y}_{\mathrm{W}} \mathrm{M}_{\mathrm{W}}
$$

\section{Losses due to reproductive failure}

$$
\mathrm{C}=\mathrm{C}_{1}+\mathrm{C}_{2}
$$

$\mathrm{C}_{1}$. Body weight loss due to increased abortions.

Reduction in number of lambs born due to increase in abortions causes loss in live body weight.
Such losses are estimated by the formulae:

$$
\mathrm{C}_{1}=\left[\left(12 / \mathrm{K}_{\mathrm{I}}\right)-\left\{12 /\left(\mathrm{K}_{\mathrm{I}}+9.5\right)\right\}\right](\mathrm{I}-\mathrm{D}) \mathrm{P}_{\mathrm{L}} \mathrm{AN}_{\mathrm{K}} \mathrm{B}_{\mathrm{W}} \mathrm{P}_{\mathrm{W}}
$$

$\mathrm{C}_{2}$. Body weight loss due to increased inter-lambing period.

Reduction in number of lambs born due to increased inter lambing period due to a disease causes loss in body weight. Such losses is estimated by the formulae:

$$
\begin{aligned}
& \mathrm{C}_{2}=\left[\left(12 / \mathrm{K}_{\mathrm{I}}\right)-\left\{12 /\left(\mathrm{K}_{\mathrm{I}}+\mathrm{W}\right)\right\}\right](\mathrm{I}-\mathrm{D}) \mathrm{P}_{\mathrm{L}}\left(1-\mathrm{A}_{\mathrm{I}}\right) \\
& \mathrm{N}_{\mathrm{K}} \mathrm{B}_{\mathrm{W}} \mathrm{P}_{\mathrm{W}}
\end{aligned}
$$

D. Loss in body weight: The value of direct loss due to reduction in body weight is estimated by the formulae:

$$
\mathrm{D}=(\mathrm{I}-\mathrm{D})\left(1-\mathrm{P}_{\mathrm{L}}\right) \mathrm{W}_{\mathrm{L}} \mathrm{W}_{\mathrm{A}} \mathrm{P}_{\mathrm{W}}
$$

where, $\mathrm{W}_{\mathrm{L}}$ is proportion of body weight loss, $\mathrm{W}_{\mathrm{A}}$ is average body weight.

\section{E. Cost of treatment $\mathrm{E}=\mathrm{IT}_{\mathrm{C}}$}

F. Opportunity costs: These costs are assumed approximately $5 \%$ of the cost of animals, i.e.

$$
\mathrm{F}=\left(\mathrm{S}_{\mathrm{AS}} \mathrm{P}_{\mathrm{AS}}+\mathrm{S}_{\mathrm{YS}} \mathrm{P}_{\mathrm{YS}}+\mathrm{S}_{\mathrm{KS}} \mathrm{P}_{\mathrm{KS}}\right) \times 0.05
$$

Where, $S_{A S}, S_{Y S}$ and $S_{K S}$ and $P_{A S}, P_{Y S}$ and $P_{K S}$ are the number of survived animals and average market values of the animals of age below 6 months, 6-12 months and more than 12 months, separately.

The treatment cost used for sheep and goat was Rs. 345 per infected animal as per details given Table- 2 .

\section{Results and Discussion}

Incidence of PPR: The number of cases and deaths due to PPR in sheep and goats during the last 5 years (20082012) are summarized in Table-3. During this period, a total of 38211 cases were reported. There was a considerable year to year variation in cases and deaths from (4496 and 1092) during 2008 to (10188 and 2041) during 2010. On an average, 7642.2 cases per year were reported by Department of Animal Husbandry, Dairying and Fisheries, Government of India. Overwhelming proportion of total number of cases was reported from eastern region (54.74\%). Morbidity of PPR in other regions, viz. southern (17.65\%), western (13.84\%) and northern $(13.77 \%)$ regions was relatively lesser. Cases of PPR were highest in rainy season (40.25\%), followed by summer season $(36.18 \%)$ and winter season (23.57\%). Hegde et al. [4] however had reported from Karnataka that the cases of PPR increased gradually during the late-monsoon and prewinter periods and the greatest number of outbreaks were observed in the winter season. The morbidity and mortality rates were also highest in Eastern region (9.86 and 2.02 per lakh) followed by other regions.

The average number of deaths due to PPR was reported as 1777.2 deaths per year. As in the case of morbidity of PPR, mortality was also highest in the eastern region $(48.08 \%)$. Other regions, reported a substantially lesser mortality rates $(21.13 \%, 18.44 \%$ and $12.35 \%$ in northern, southern and western regions, respectively). Highest mortality occurred in rainy season $(38.98 \%)$, followed by summer $(36.87 \%)$ and 
Table-3. Region and season wise average number of cases and deaths in sheep and goats

\begin{tabular}{|c|c|c|c|c|c|c|c|c|c|c|}
\hline \multirow[t]{2}{*}{ Region } & \multicolumn{2}{|c|}{ Summer } & \multicolumn{2}{|c|}{ Rainy } & \multicolumn{2}{|c|}{ Winter } & \multicolumn{2}{|c|}{ Total } & \multicolumn{2}{|c|}{ Percentage } \\
\hline & Cases & Deaths & Cases & Deaths & Cases & Deaths & Cases & Deaths & Cases & Deaths \\
\hline East & 1780.8 & 360.8 & 1576.6 & 310.6 & 825.8 & 193.2 & 4183.2 & 854.4 & 54.74 & 48.08 \\
\hline West & 220.4 & 47.6 & 509.4 & 123.4 & 328 & 48.4 & 1057.8 & 219.4 & 13.84 & 12.35 \\
\hline North & 495.6 & 153 & 482.6 & 188.2 & 73.8 & 34.4 & 1052 & 375.6 & 13.77 & 21.13 \\
\hline South & 267.8 & 93.8 & 507.2 & 70.6 & 574.2 & 163.4 & 1349.2 & 327.8 & 17.65 & 18.44 \\
\hline Total & 2764.6 & 655.2 & 3075.8 & 692.8 & 1801.8 & 439.4 & 7642.2 & 1777.2 & 100 & 100 \\
\hline Percentage & 36.18 & 36.87 & 40.25 & 38.98 & 23.57 & 24.72 & 100.00 & 100.00 & & \\
\hline
\end{tabular}

Cases: $\chi_{(\text {cal) }}^{2}=40.66$ Sig. $(P<0.001)$, Deaths: $\chi_{(\text {cal })}^{2}=12.10$ Sig. $(P<0.05)$

Table-4. Estimates of parameters for PPR effects in goats

\begin{tabular}{|c|c|c|c|c|}
\hline Parameters & Notation & Goat & Sheep & Source of information \\
\hline Number of infected animals & 1 & 5426 & 2216 & {$[19,20]$} \\
\hline Number of animals died & $\mathrm{D}$ & 1294 & 483 & {$[19,11]$} \\
\hline Proportion of sheep in shearing age (\%) & $P_{H}$ & - & 0.80 & [19] \\
\hline Proportion of animals in lactation (\%) & $\mathrm{P}_{\mathrm{L}}$ & 0.33 & 0.41 & {$[19,11]$} \\
\hline Average annual milk yield in $\mathrm{kg}$ & Z & 61.5 & - & [21] \\
\hline Average annual wool yield $(\mathrm{kg})$ & $Y_{w}$ & - & 0.91 & [19] \\
\hline Average market value of animal (Rs.) & $\mathrm{V}$ & 4500 & 4000 & [10] \\
\hline Increased abortion rate (\%) & $A$ & 28 & 33 & [11] \\
\hline Proportion of lactation lost (\%) & $\mathrm{L}$ & 15 & - & Probable value \\
\hline Proportion of wool yield lost (\%) & $Y_{L}$ & - & 0.20 & Probable value \\
\hline Price of wool per $(\mathrm{kg})$ & $\mathrm{M}_{\mathrm{w}}$ & - & 60 & Probable value \\
\hline Kidding / lambing interval (months) & $\mathrm{K}_{1}$ & 9 & 9 & Probable value \\
\hline Price of milk per kg (Rs.) & M & 20 & - & Probable value \\
\hline Delay in conception (months) & W & 2 & 2 & Probable value \\
\hline Price of live weight per kg (Rs.) & $P_{w}$ & 300 & 300 & Probable value \\
\hline Treatment cost of an infected animal (Rs.) & $\mathrm{T}_{\mathrm{C}}$ & 345 & 345 & [22] \\
\hline Number of live kids born & $\mathrm{N}_{\mathrm{K}}$ & 1.5 & 1 & Probable value \\
\hline Birth weight (kg) & $\mathrm{B}_{\mathrm{w}}$ & 2.5 & 2.5 & Probable value \\
\hline Average body weight (kg) & $\mathrm{W}_{\mathrm{A}}$ & 25 & 25 & Probable value \\
\hline Proportion of body weight lost (\%) & $W_{L}$ & 20 & 20 & {$[11]$} \\
\hline Price of new born kid & $\mathrm{P}_{\mathrm{C}}$ & 750 & 600 & Probable value \\
\hline
\end{tabular}

winter (24.72\%), respectively.

Chi-square analyses revealed that distribution of cases and deaths in sheep and goats due to PPR across regions and seasons are significantly interdependent. In eastern region, the maximum number of cases and deaths were reported during summer months. In western region, highest number of cases and deaths were observed in rainy season. In northern region, highest number of cases and deaths was registered in summer and rainy seasons, respectively. In southern region, maximum number of cases and deaths were reported in winter season.

The average number of infected and died sheep and goats due to PPR during the last five years (200812) are given in Table-4. Considering the population of goats and sheep in the year 2007 (Livestock Census Report), the average annual morbidity rates due to PPR in India were $0.0039 \%$ and $0.0031 \%$, respectively. The mortality rates in these respective species were 9.21 and 6.75 per million of population. As per the sample surveys under post graduate research projects $[10,11]$, the estimated morbidity and mortality rates were $13.07 \%$ and $6.12 \%$ in goats and $21.85 \%$ and $10.92 \%$ in sheep, respectively. Thombare and Sinha [9] in an outbreak study, reported prevalence rate of PPR in Pune district of Maharashtra to be $52.99 \%$ and $51.17 \%$ in sheep and goats, respectively. Mahajan et al. [14] reported from Jammu region higher prevalence rate of PPR in goats $(66.66 \%)$ than in sheep $(35.71 \%)$. Tiwari
[15] reported prevalence of PPR of $36.7 \%$ in small ruminant population in Gujarat; $39.16 \%$ in sheep and $35.9 \%$ in goats.

Estimation of economic losses due to PPR: Component-wise losses due to PPR in sheep and goats as calculated by the methodology adopted in this study - based on average number of cases and death reported by Government of India - are given in Tables-5 and 6. Mortality and morbidity losses, respectively, contributed $34.34 \%$ and $65.66 \%$, of total loss (Rs. 125.67 lacs) due to PPR in goats (Table-5). Disaggregated analysis revealed that among different components of losses, the maximum loss was observed due to direct body weight loss (33.05\%). Losses due to treatment cost, reproductive failure and opportunity costs were the next major components of morbidity loss accounting for $14.90 \%, 9.37 \%$ and $6.34 \%$ of total loss, respectively. Direct milk loss accounted for the smallest proportion of total loss $(2.01 \%)$.

In case of sheep, mortality loss accounted for $33.78 \%$ of total loss while morbidity contributed 66.22\% of total loss (Rs. 42.16 lacs) due to PPR. Direct body weight loss contributed the highest proportion $(36.39 \%)$ of total loss, followed by treatment cost (18.15\%), opportunity costs (6.43\%) and losses due to reproductive failure $(4.91 \%)$. Wool loss accounted for negligible share of total loss $(0.36 \%)$ (Table-6).

Total annual economic loss due to PPR in small ruminants was thus estimated as Rs. 167.83 lacs. 
Table-5. Component and species wise losses due to PPR in goats (Rs. In lacs)

\begin{tabular}{lcc}
\hline Components & Value & \% loss \\
\hline 1. Mortality loss & 43.16 & 34.34 \\
2. Morbidity loss & & \\
i. Direct Milk loss & 2.52 & 2.01 \\
ii. Reproductive failure & & \\
a. Milk loss due to increased Interkidding period & 2.93 & \\
b. Milk loss due to increased abortions & 3.21 & \\
c. Kids loss due to increased Interkidding period & 2.68 & \\
d. Kids loss due to increased abortion & 2.94 & \\
Total loss due to reproductive failure & 11.77 & 9.37 \\
iii. Direct Body weight loss & 41.53 & 33.05 \\
iv. Treatment cost & 18.72 & 14.90 \\
v. Opportunity Cost & 7.97 & 6.34 \\
Total morbidity loss & 82.51 & 65.66 \\
Total loss & 125.67 & 100 \\
\hline
\end{tabular}

Losses due to PPR in goats was higher (74.88\%) as compared to sheep $(25.12 \%)$.

The computation of economic losses due to PPR were computed on the basis of Government of India data and data reported from sample survey studies [10, 11]. (morbidity and mortality rates of $13.07 \%$ and $6.12 \%$ in goats and $21.85 \%$ and $10.92 \%$ in sheep, respectively) considering the values of different parameters given in Tables 4 and 5 .

In the present study, efforts were made to develop methodology for evaluation of economic losses considering all possible direct and indirect losses due to PPR in goats and sheep. In a few earlier studies, attempts were made to model economic losses due to diseases in large ruminants $[16,17]$. In case of small ruminants, limited work has been carried out to model economic losses due to diseases in goats [6] and sheep [18]. However, in these studies the annual economic losses were estimated based on Government of India data only. In the present study, a model was developed to estimate the economic losses due to PPR at the national level by considering both the Government of India data and sample survey studies.

The annual economic loss estimated on the basis of data reported by Department of Dairying Animal Husbandry and Fisheries, Government of India (Rs. 167.83 lacs) was too low, probably on account of under reporting of cases and deaths due to the disease. Based on cases and deaths as reported in sample survey studies, the estimated annual economic loss due to peste des petits ruminants disease in goats and sheep at the national level is Rs. 8895.12 crores, of which Rs. 5477.48 and Rs. 3417.64 crores are due to the incidence of the disease in goats and sheep, respectively.

\section{Conclusion}

In the present study, morbidity losses constituted the greater share of the total loss in both goats and sheep (65.66\% and $66.22 \%$, respectively). Among different components of morbidity loss, direct body weight loss was the most significant in both goats and sheep. The study thus revealed a significant loss due to PPR in small ruminants on a large scale. There is thus ample scope for preventive measures to control the
Table-6. Component and species wise losses due to PPR in sheep (Rs. In lacs)

\begin{tabular}{lcc}
\hline Components & Value & \% loss \\
\hline Components & Value & $\%$ loss \\
1. Mortality loss & 14.24 & 33.78 \\
2. Morbidity loss & & \\
l. Direct Wool loss & 0.15 & 0.36 \\
ii. Direct Body weight loss & 15.34 & 36.39 \\
iii. Losses due to reproductive failure & & \\
a. Body weight loss due to increased & 0.87 & \\
Inter-lambing period & & \\
b. Body weight loss due to increased abortions & 1.20 & \\
Total loss due to reproductive failure & 2.07 & 4.91 \\
iv. Treatment cost & 7.65 & 18.15 \\
v. Opportunity Cost & 2.71 & 6.43 \\
Total morbidity loss & 27.92 & 66.22 \\
Total loss & 42.16 & 100 \\
\hline
\end{tabular}

disease in goats and sheep.

\section{Authors' contributions}

The present study is the part of Institute sponsored research project 'Estimation of economic losses due to important diseases in livestock in India' sponsored by Indian Veterinary Research Institute, Izatnagar. BS is the principal investigator of the project, designed the study and approved the final format of the paper. DB is associate in the project, assisted in research design, carried out literature review, analysis of data and drafted the manuscript. MRV and SP assisted in research design, carried out literature review, reviewed the manuscript and provided suggestions. DKS provided epidemiological inputs, computed the treatment cost and provided suggestions. All authors read and approved the final manuscript.

\section{Acknowledgements}

The authors are thankful to Joint Director Research, Indian Veterinary Research Institute, Izatnagar, Uttar Pradesh, India for providing facilities and funds for this project.

\section{Competing interests}

The authors declare that they have no competing interests.

\section{References}

1. Fentahun, T. and Woldie, M. (2012) Review on Perste des petits ruminants (PPR), Eur JAppl Sci, 4(4): 160-167.

2. Gopilo, A. (2005) Epidemiology of Peste des petits ruminants virus in Ethiopia and molecular studies on virulence, (Ph.D. Thesis, De'L Institut National Polytechnique De Toulouse, France)

3. Singh, R.P. (2011) Control strategies for peste des petits ruminants in small ruminants in India, Revue Scientifique et Technique, 30(3): 879-887.

4. Hegde, R., Gomes, A.R., Muniyellappa, H.K., Byregowda, S.M., Giridhar, P. and Renukaprasad, C. (2009) A short note on peste des petits ruminants in Karnataka, Revue Scientifique et Technique, 28(3): 1031-1035.

5. Balamurugan, V., Sen, A., Venkatesan, G., Yadav, V., Bhanuprakash, V. and Singh, R.K., (2010) Isolation and identification of virulent peste des petits ruminants viruses from PPR outbreaks in India, Trop Anim Health Prod, 42:1043-1046.

6. Singh, B. and Prasad, S. (2008a) Modelling of economic losses due to some important diseases in goats in India, 
Agril. Econ. Res. Review, 21:297-302.

7. Zewdie, S. (2009) In: Yami, A.; Merkel, R.C. and Dawson, L. (Eds.) Peste des Petits Ruminants (PPR), Technical Bulletin No. 20, pp. 1-4, Ethiopia Sheep and Goat Productivity Improvement Programme, USAID and MoARD, Ethiopia (http://www.esgpip.org/PDF/Technical\%20bulletin\%20No. 20.pdf). Accessed on 26-12-2013.

8. Singh, R.P., Saravanan, P., Sreenivasa, B.P., Singh, R.K. and Bandyopadhyay, S.K. (2004) Prevalence and distribution of peste des petits ruminants virus infection in small ruminants in India, Revue Scientifique et Technique, 23(3): 807-819.

9. Thombare, N.N. and Sinha, M.K. (2009) Economic implications of Peste des petits ruminants (PPR) disease in sheep and goats: A sample analysis of district Pune, Maharashtra, Agril Econ. Res Rev, 22:319-322.

10. Awase, M. (2012) Estimation of economic losses due to prominent diseases of ruminants in Indore division of Madhya Pradesh, (MVSc Thesis, Indian Veterinary Research Institute).

11. Sahu, B. (2013) Analysis of morbidity and mortality due to FMD and PPR in livestock of Chhattisgarh, (MVSc Thesis, Indian Veterinary Research Institute).

12. Khan, M.I., Hussain, S.N., Bahadar, S., Ali, A. and Shah, I.A. (2008) An outbreak of peste des petits ruminants (PPR) in goats in district Chitral, N.W.F.P., Pakistan, ARPN Journal of Agricultural and Biological Science, 3(2): 19-22.

13. El-Yuguda, A-D., Baba, S.S., Ambali, A.G. and Egwu, G.O. (2013) Seroprevalence of peste des petits ruminants among domestic, small and large ruminants in the semi-arid region of North-eastern Africa, Vet World, 6: 807-811.

14. Mahajan, S., Agrawal, R., Kumar, M., Mohan, A. and Pande, N. (2013) Incidence of peste des petits ruminants in nomadic sheep and goat of Jammu region, Vet World, 6(7):384-387.

15. Tiwari, A. (2004) Prevalence of peste des petitis ruminants (PPR) virus in small ruminants of Gujarat and its characterization by RT-PCR/RFLP and SSCP profiles. (MVSc Thesis, Anand Agricultural University).

16. Singh, B., Prasad, S., Sinha, D.K. and Verma, M.R. (2013) Estimation of economic losses due to foot and mouth disease in India, Indian J Anim Sci, 83(9): 964-970.

17. Singh, B. and Prasad, S. (2008b) Economic evaluation of important cattle diseases in India. Indian Vet J, 85(11): 1207 10.

18. Singh, B. and Prasad, S. (2009) A model assessment of economic losses due to some important diseases in sheep in India. Indian J Anim Sci, 79(12): 1265-68.

19. Government of India. (2012) Basic Animal Husbandry Statistics (BAHS)-2012. Department of Animal Husbandry, Dairying and Fisheries, Ministry of Agriculture.

20. Balamurugan, V., Saravanan, P., Sen, A., Rajak, K.K., Venkatesan, G., Krishnamoorthy, P., Bhanuprakash, V. and Singh, R.K. (2012) Prevalence of Peste des petits ruminants among sheep and goats in India, $J$ Vet Sci, 13(3): 279-285.

21. Singh. M.K., Dixit, A.K., Roy, A.K. and Singh, S.K. (2013) Goat rearing: A pathway for sustainable livelihood security in Bundelkhand region, Agril Econ. Res Rev, 26:79-88.

22. Chakrabarti, A. (1997) A Text Book of Preventive Veterinary Medicine, Kalyani Publishers, India.

$* * * * * * * *$ 